Jurnal Pemberdayaan: Publikasi Hasil Pengabdian kepada Masyarakat

Vol. 2, No. 2, Agustus 2018, Hal. 221-234

ISSN: 2088 4559; e-ISSN: XXXX-XXXX

DOI:

\title{
PELATIHAN NST (NIJMEEGSE SCHOOLBEKWAN TEST) UNTUK DETEKSI DINI KESIAPAN ANAK MASUK SEKOLAH DASAR SEBAGAI BENTUK PROFESIONALISME GURU
}

\author{
Avanti Vera Risti Praudyani ${ }^{1}$ Ega Asnatasia Maharani ${ }^{2}$ \\ Universitas Ahmad Dahlan, Yogyakarta ${ }^{1,2}$ \\ avanti.pramudyani@pgpaud.uad.ac.id ${ }^{1}$
}

\begin{abstract}
ABSTRAK
Kesiapan sekolah seharusnya menjadi bagian deteksi dini yang dilakukan guru dalam lingkup PAUD. Kemampuan guru mengadministrasikan tes NST dapat digunakan untuk mendeteksi kesiapan sekolah untuk memasuki jenjang SD akan memberikan informasi penting bagi pendidikan anak di level selanjutnya. Deteksi dini kesiapan anak memasuki jenjang SD dapat dilakukan dengan menggunakan NST. (Nijmeegse Schoolbekwan Test). Kegiatan pengabdian kepada masyarakat ini bertujuan untuk memberikan pengetahuan dan wawasan, serta keterampilan kepada guru tentang kesiapan anak memasuki jenjang SD dalam mengunakan alat deteksi dini NST. Melalui pelatihan ini guru juga dapat meningkatkan kompetensi profesional terutama dalam melakukan evaluasi terhadap kemampuan anak yang siap memasuki jenjang SD. Sasaran utama pelatihan adalah guru TK dibawah naungan PCA Umbuharjo. Metode pelaksanaan kegiatan meliputi ceramah, diskusi, praktek, dan Self and Group Reflection. Materi pengabdian terdiri dari tiga materi besar yaitu konsep kesiapan sekolah, konsep dasar NST, dan praktek penggunaan NST. Hasil dari kegiatan pengabdian ini ialah pelatihan ini sangat diminati oleh para guru terlihat dari jumlah peserta dan asal sekolah yang melebihi target. Kendala yang dialami peserta pengabdian ketika melakukan pengetesan kepada peserta didik ialah peserta pengabdian (guru) kesulitan untuk mendapatkan data dari seluruh pertanyaan tes karena keterbatasan waktu dengan peserta didik dan kondisi peserta didik yang tergolong moody.
\end{abstract}

Kata kunci: NST, Deteksi, Stimulasi, Kesiapan Sekolah, Kompetensi guru

\begin{abstract}
The school readiness should be a part of early detection is done within the scope of the teacher in ECE. The ability of the teacher to archive the result of the test NST can be used to detect the school of readiness to enter Elementary School will provide important information for the education of the children of the next level. Early detection of the readiness of children entering the Elementary School level can be done by using the NST. (Nijmeegse Schoolbekwan Test). The activities of the Community aims to provide knowledge and insights, as well as the skills to the teacher about the school of readiness of children entering the Elementary School level in using the tool of early detection of NST. Through this training, teachers can also improve professional competence especially in doing the evaluation of the ability of the child who is ready to enter Elementary School level. Main target training is the kindergarten teacher under the auspices of the PCA Umbuharjo. Methods of implementation activities include lectures, discussion, practice, and Self and Group Reflection. Material service consists of three large materials i.e. school readiness concepts, basic concepts, and practice the use of the NST NST. The result of the activities of this devotion is in great demand this training by teachers can be seen from the number of participants and the origin of schools that exceed the target. The constraints experienced by participants of devotion when doing testing to students is community service participants (teachers) the difficulty to get the data from the entire question of tests because of limited time with learners and learners who belongs to moody.
\end{abstract}

Keywords: NST, detection, stimulation, school readiness, teacher competence 


\section{PENDAHULUAN}

Kota pendidikan selalu disematkan kepada Kota Yogyakarta, hal tersebut memberikan pengaruh kepada Kota Yogyakarta sebagai salah satu barometer dalam perkembangan pendidikan di Indonesia. Dengan predikat tersebut Yogyakarta menjadi salah satu referensi dan tujuan pendidikan bagi berbagai praktisi maupun akademisi. Pertumbuhan pendidikan baik secara kualitas dan kuantitas juga sejalan dengan sektor ekonomi. Pertumbuhan dalam bidang ekonomi dan sosial yang sangat pesat, jumlah pendatang yang terus bertambah menjadikan kota ini seperti megapolitan. Dahulu Yogyakarta hanya dijadikan sebagai kota tujuan pendidikan, namun berkembangnya kota ini banyak masyarakat yang memilih untuk menetap. Dampk di dunia pendidikan yang paling dirasakan adalah bermunculan sekolah baru untuk mengakomodir peningkatan jumlah penduduk. Dilansir dari Pusat Data Statitik Pendidikan dan Kebudayaan, Kementerian Pendidikan dan Kebudayaan diperoleh informasi per tahun 2016/2017 jumlah sekolah di Provinsi DIY tercatat 2.138 sekolah dengan jumlah anak didik 98.538 dan guru sebanyak 9.243 orang (Kebudayaan, 2017). Jumlah tersebut meningkat cukup tinggi dibandingkan pada tahun 2007/2008, data yang diperoleh dari www.pemda-diy.go.id menunjukkan jumlah sekolah TK di DIY hanya 1.901 sekolah.

Tingginya jumlah sekolah yang baru di Yogyakarta belum sepenuhnya diiringi dengan peningkatan mutu pendidikan. Peningkatan kualitas pendidikan dapat dilihat dari profesionalisme guru yang wajib dimiliki oleh setiap pendidik khususnya jenjang PAUD. Data statistik tahun 2014 yang dirilis oleh Kementerian Pendidikan dan Kebudayaan terdapat 948 guru PAUD memiliki kualifikasi bukan S1 PAUD. Jumlah guru yang belum berkualifikasi S1 juga masih sangat besar terdapat 4.753 guru PAUD yang hanya berijazah SMA (Kementerian Pendidikan dan Kebudayaan, 2014). Pengaruh dari ketidaksesuaian kualifikasi guru tersebut adalah proses pembelajaran karena guru memiliki peran sentral dalam tahap tersebut. salah satu dampak dari proses pembelajaran yang tidak maksimal adalah kesiapan anak untuk masuk SD semakin jauh dari kematangan.

Peristiwa kelulusan anak menyelesaikan jenjang TK dan memasuki SD adalah hal yang paling diresahkan orangtua. Momen tahun ajaran baru tersebut menjadi masa yang paling mengkhawatirkan bagi orangtua selain harus memikirkan biaya, orangtua juga masih terbebani dengan kondisi kesiapan anak memasuki lingkungan baru. Banyak ditemui pemandangan orangtua harus masuk ke dalam kelas di awal masa sekolah. Meskipun hal tersebut tidak dilarang bahkan telah dikeluarkan surat Edaran dari Kementerian Pendidikan dan Kebudayaan melalui Direktorat Pembinaan Pendidikan Keluarga mencanangkan 
“Gerakan Mengantar Anak di Hari Pertama Sekolah" pada tanggal 11 Juli 2016. Himbauan tersebut hal tersebut belum signifikan dalam meningkatkan kesiapan anak di sekolah baru hal tersebut terlihat dari masih banyaknya orangtua usia dini masih menemani anak sampai dengan beberapa minggu berikutnya.

Ketidaksiapan anak usia dini memasuki lingkungan baru di SD dikarenakan perubahan pola belajar yang sangat jauh berbeda, seperti jumlah jam, jenis, dan kegiatan pembelajaran yang dilakukan. Selain perubahan lingkungan belajar, kesiapan juga dipengaruhi oleh usia biologis anak, berdasarkan peraturan perundang-undangan usia yang ideal untuk anak usia dini masuk SD adalah 7 tahun. Meskipun terdapat aturan yang mengatur tentang batas usia anak, namun masih banyak ditemui anak yang belum berusia tujuh tahun diterima di SD dengan pertimbangan kurangnya kuota peserta didik atau anak sudah mampu mengusai kemampuan menulis, membaca, dan berhitung. Sebagaimana yang disampaikan Kepala SDN Petinggen Yogyakarta Dwi Kuntari Isninawati, menyatakan bahwa bila kuota 28 siswa belum terpenuhi, sekolah dapat menerima siswa dengan usia kurang dari 7 tahun (Natalia, 2013). Kedua hal tersebut tidak dapat dijadikan sebagai tolak ukur bahwa kesiapan anak memasuki jenjang pendidikan dasar atau SD. Hal tersebut didukung oleh Peraturan Bersama antara Menteri Pendidikan Nasional dan Menteri Agama Nomor 2/VII/PB/2014 Bab II pasal 4 Tahun 2014 dan Nomor 7 Tahun 2014 tentang Persyaratan usia calon peserta didik baru kelas 1 (SD/SDLB/MI) telah berusia 7 tahun wajib diterima.

Kesiapan anak memasuki jenjang SD dapat dilakukan sejak awal melalui layanan pendidikan TK B. Guru TK B dapat terlebih dahulu melakukan screening tes ketika anak memasuki kelompok B untuk mengetahui kesiapan anak sehingga apabila secara psikologis didapati anak yang belum siap dapat distimulasi, sehingga ketika memasuki jenjang SD anak telah memiliki kesiapan. Screening tes sejak dini sebagai langkah preventif agar guru mengetahui kesiapan anak masuk SD bukanlah sesuatu yang mudah. Berdasarkan hasil wawancara dengan 6 kepala sekolah PAUD di kota Yogyakarta, Kabupaten Gunung Kidul, dan Kabupaten Sleman diperoleh informasi bahwa tidak ada deteksi dini di awal penerimaan peserta didik. Tanpa adanya deteksi dini diawal sekolah menjadikan guru tidak memiliki rekam perkembangan anak. Untuk mengetahui perkembangan anak, orangtua dapat memperoleh Laporan Perkembangan atau biasa disebut raport yang diberikan guru setiap 6 bulan sekali. Guru tidak melalukan deteksi secara berkala dikarenakan guru tidak memiliki pengetahuan dan keterampilan akan hal tersebut. 
Selama ini deteksi dini dianggap hanya dapat dilakukan oleh profesi dengan latar belakang medis atau ilmu murni seperti dokter, psikolog, atau bidan. Pemahaman ini seringkali menghambat proses pendidikan karena guru kurang dilibatkan dalam proses asesmen perkembangan. Hal inilah yang sering ditemukan dalam kasus ketidaksiapan anak di tingkat SD. Sesuai dengan hasil penelitian (Deliviana, 2017), kesiapan anak masuk SD tidak hanya ditentukan oleh usia kronologis tetapi juga dikarenakan aspek perkembangan kognitif, bahasa, motorik, sosialemosional, dan kemandirian anak, serta dukungan lingkungan seperti keluarga dan sekolah.

Kesiapan sekolah atau school readiness menurut Janus \& Gaskin (2014), kematangan sistem neuron atau saraf pada anak untuk mengembangkan berbagai kemampuan dasar yang berasal dari stimulasi yang diterimanya. Dalam kesiapan sekolah terdapat kesiapan belajar, dengan kata lain ketika seorang anak memiliki kesiapan sekolah dijenjang tertentu maka dia memiliki kesiapan belajar sehingga dapat menerima semua bentuk pembelajaran. Hal tersebut dijelaskan oleh Kagan (1990), kesiapan untuk belajar sama seperti tingkat atau level perkembangan seorang individu untuk siap menerima pembelajaran secara spesifik. Secara spesifik kesiapan sekolah dapat dikatakan sebagai serangkaian aspek meliputi kesehatan fisik anak dan well-being, kemampuan sosial, kematangan emosional, pendekatan untuk belajar, perkembangan bahasa dan kognitif, dan kemampuan berkomunikasi (Janus, et al., 2007).

Kesiapan sekolah selalu diasosiasikan dengan penguasaan akan kemampuan spesifik yang dibutuhkan dalam lingkungan sekolah seperti duduk dengan tenang dikelas dan merespon setiap instruksi guru (Kagan M. , 1992). Janus \& Gaskin (2014), menambahkan kesiapan sekolah adalah kematangan yang menekankan pada kemampuan yang dibutuhkan anak dengan kebutuhan sekolah yang terdiri dari aspek kognitif, fisik, dan sosial. Kebutuhan yang diinginkan oleh sekolah antara lain bekerja bersama, mendengarkan guru, dan manfaat lain yang akan diperoleh selama aktivitas pendidikan yang disediakan sekolah (Janus, et al., 2007). Untuk memperoleh gambaran kesiapan sekolah anak terutama memasuki jenjang SD dapat dilakukan dengan bantuan alat tes psikologi yang sederhana dan dapat dilakukan oleh guru.

Mengetahui kesiapan anak dapat dilakukan melalui berbagai metode salah satunya dengan menggunakan NST. (Nijmeegse Schoolbekwan Test). NST adalah alat tes yang dirancang oleh Prof. F.J. Monks, Drs. H. Rost and Drs. N.H. Coffie pada tahun 1978. Instrumen ini digunakan untuk mengukur kematangan terkait aspek perkembangan yang mendukung kesiapan anak memasuki jenjang SD. Pada awalnya NST digunakan untuk 
mengungkap kemampuan sekolah anak, kemudian dikembangankan menjadi alat ukur tingkat kematangan dan kesiapan anak masuk SD, memberikan prognosis terhadap prestasi belajar anak, dan memetakan kemampuan apa yang sudah/belum berkembang sehingga dapat dilakukan upaya pembinaan lebih lanjut. Struktur tes NST terdiri dari Form A untuk mengukur kematangan sekolah, dan form B untuk evaluasi. Adapun sub-test dalam alat ukur ini meliputi: (1) pengamatan dan kemampuan membedakan, (2) motorik halus, (3) pengertian tentang jumlah, ukuran dan perbandingan, (4) ketajaman pengamatan, (5) pengamatan kritis, (6) konsentrasi, (7) daya ingat, (8) pengertian tentang objek dan penilaian tentang situasi, (9) memahami cerita, (10) mengambar orang ( Monks, F. J., Rost, H., \& Coffie, N. H., 1978).

NST bagi guru berbentuk kuesioner yang disesuaikan dengan tujuan untuk membantu mendekripsikan perilaku dan kematangan anak berdasarkan asesment. Kuesioner tersebut mengembangkan aspek perilaku secara teoritis yang dilakukan oleh Kemmler \& Hekhausen. Beberapa contoh aspek yang dilihat antara lain: bagaimana anak pergi atau keluar rumah, bagaimana anak kontak dengan anak sebaya, apakah anak mencari dukungan dari gurunya, bagaimana anak menyesuaikan diri dengan situasi belajar, dan anak memiliki keinginan untuk berprestasi dan mandiri. Terdapat tiga aspek perilaku yang muncul dalam daftar pertanyaan di NST., yaitu; 1) Sociale San Passing (kemampuan sosial) yang bertujuan untuk melihat tingkat perilaku anak dalam sebuah kelompok; 2)Taakbesef of weekbekwaamheid (belajar bersikap) untuk melihat kesiapan, kesungguhan, dan ketekunan anak dalam melakukan tugasnya; dan 3) Zelfsatndigheid (kemandirian), melihat kemampuan anak dalam melakukan suatu tugas tanpa adanya bantuan dan dorongan (Monks, F. J., Rost, H., \& Coffie, N. H., 1978).

Mengukur kesiapan anak dengan NST merupakan salah satu alternatif yang sesuai bagi guru agar mampu mengetahui tingkat kematangan anak. Mengetahui gambaran kesiapan dan kematangan anak sangat diperlukan bagi anak usia dini di Indonesia mengingat aturan yang diberlakukan anak usia dibawah 6 tahun bisa masuk jenjang SD. sebagaimana hasil penelitian dari (Mariyati \& Affandi, 2016), NST mampu mengukur kematangan anak sebagai indikator kesiapan sekolah pada konteks Pendidikan di Indonesia. NST juga dapat digunakan bagi anak usia dini yang akan masuk ke SD sesuai dengan hasil penelitian (Sartika, Halimah, \& Annisa, 2011). Pengetahuan dan keterampilan dalam melakukan deteksi dini kesiapan anak masuk SD akan bermanfaat bagi guru sekaligus bagi anak dan orangtua.

Kesiapan anak menurut Freud menjadi modal utama dalam mendidik karena anak yang siap atau matang akan lebih mudah menerima pengetahuan baru. Hal tersebut sesuai dengan 
hasil penelitian Hasil penelitian (Wiwik , 2005) tentang Kesiapan bersekolah anak di Kota Yogyakarta menyatakan bahwa, anak yang memiliki kesiapan sekolah akan memperoleh keuntungan dan kemajuan dalam perkembangan selanjutnya. Begitu pula sebaliknya, anak yang tidak siap ke sekolah akan frustasi dan menunjukkan perilaku menarik diri, berlaku acuh tak acuh, menunjukkan gejala-gejala fisik, atau kesulitan menyelesaikan tugasnya di sekolah, sehingga anak tidak siap berpartisipasi dalam kegiatan pembelajaran dan aktivitas di kelas yang berdampak pada penurunan prestasi belajar anak.

Melalui pelatihan diharapkan guru dapat mengaplikasikan dalam awal proses pembelajaran sehingga guru mampu memetakan anak yang telah dan belum mencapai kematangan. Hasil tes ini juga dapat digunakan guru sebagai deteks dini sebagai dasar dalam menyusun kegiatan pembelajaran bagi anak agar kemampuan anak berkembang maksimal dana memiliki kesiapan memasuki jenjang SD.

\section{METODE}

\section{A. Metode Pelatihan}

Pelatihan NST. (Nijmeegse Schoolbekwan Test) Untuk Deteksi Dini Kesiapan Anak Masuk Sekolah Dasar dilaksanakan dengan beberapa metode. Pertimbangan dalam memilih metode disesuaikan dengan materi dan tujuan dari setiap sesi pelatihan agar hasilnya sesuai dengan yang direncanakan. Metode menurut (Sanjaya, 2010), merupakan cara yang digunakan untuk mengimplementasikan sebuah rencana yang disusun sebelumnya dalam kegiatan nyata agar sesuai dengan tujuan awal dan berhasil secara optimal. Beberapa metode yang digunakan dalam pelatihan ini yaitu:

\section{Ceramah}

Metode ceramah digunakan untuk menyampaikan materi secara lisan atau verbal dengan media suara dan fasilitator. Dalam pelatihan ini metode ceramah digunakan ketika diawal sesi untuk menyampaikan materi secara umum (Sanjaya, 2010).

\section{Diskusi}

Metode ini merupakan metode yang melibatkan dua individu atau lebih untuk saing bertukar infromasi secara verbal, dengan salng berhadapan, saling mempertahankan pendapat dengan tujuan memecahkan sebuah masalah. Penggunaan metode ini selama pelatihan dilakukan untuk memberikan pemahaman lebih dalam kepada peserta dalam memecahkan permasalahan terkait indikator kesiapan anak (Sanjaya, 2010). 
3. Praktek

Metode ini merupakan salah satu upaya dalam memberikan pengalaman langsung kepada anak didik, guru tidak hanya memberikan instruksi serta penjelasan materi di depan kelas namun kegiatan juga dilakukan dengan praktek langsung. Metode ini digunakan pada saat kegiatan pelatihan setelah peserta mendapatkan teori (Sanjaya, 2010).

\section{Self and Group Reflection}

Metode ini digunakan pada saat kegiatan dengan melibatkan kelompok kecil yang terdiri dari peserta pelatihan. Penggunaan metode ini juga bertujuan memberikan kemampuan kepada setiap peserta untuk mengkomunikasikan pengetahuan atau keterampilan yang dimiliki dalam sebuah kelompok. Dengan metode ini dapat mengembangkan kemampuan untuk membangun suasana kerja yang sehat antar peserta baik pada saat proses pelatihan atau setelah kembali ke lembaga (Angelo \& Cross, 1993).

\section{B. Materi Pelatihan}

Tabel 1. Materi yang diberikan dalam Workshop

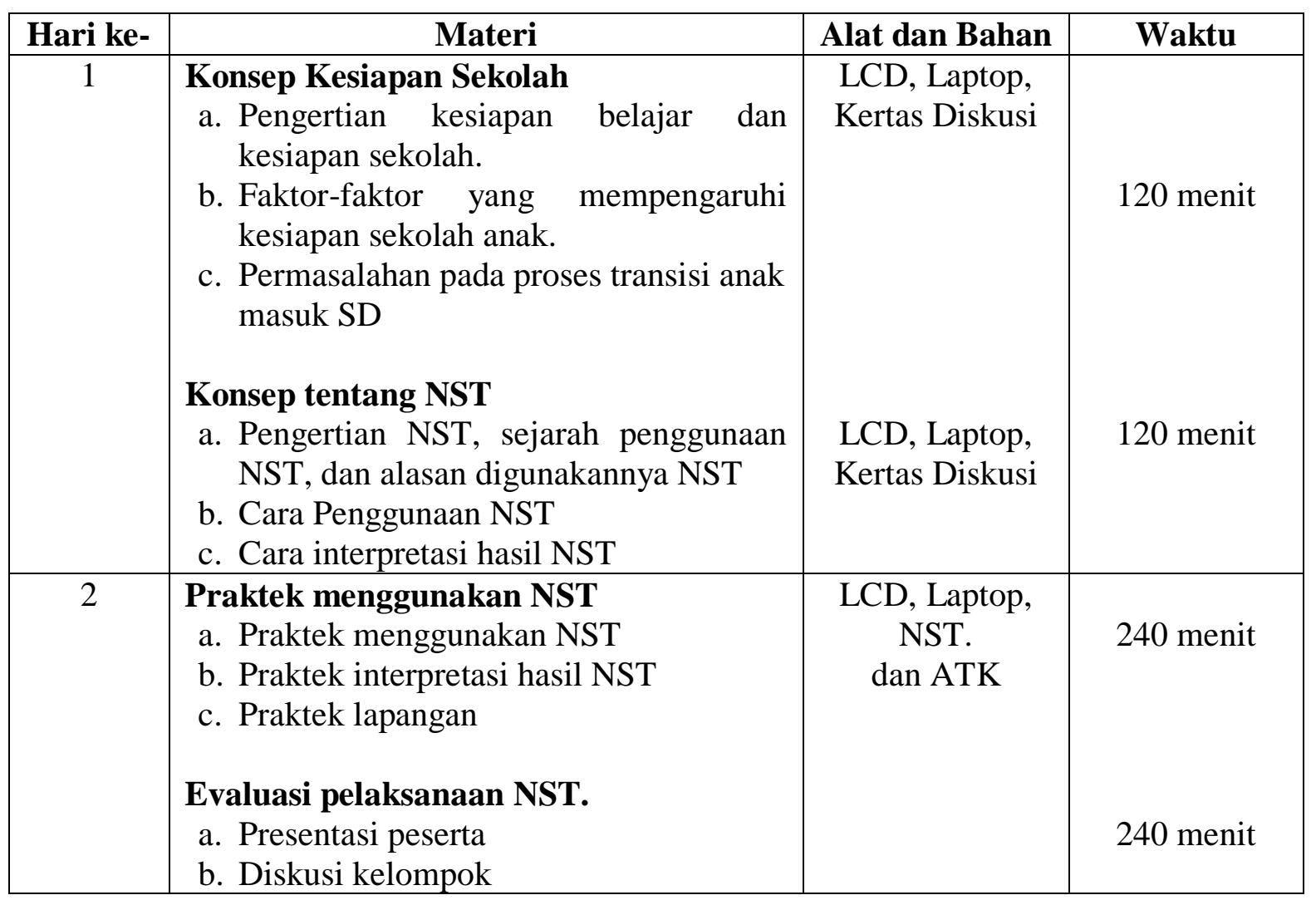


Pelatihan dilanjutkan dengan adanya proses pemantauan kegiatan untuk mengetahui kemajuan dan pengembangan program lebih kurang satu bulan setelah workshop selesai. Pemantaun terdiri dari proses implementasi NST. (Nijmeegse Schoolbekwan Test).

\section{HASIL, PEMBAHASAN, DAN DAMPAK}

\section{A. HASIL PELATIHAN}

Pelatihan ini pada awalnya diperuntukan bagi guru TK B dengan pertimbangan, mereka akan membimbing anak sebelum memasuki jenjang Sekolah Dasar. Namun guruguru dari layanan TK A memiliki keinginan untuk mendapatkan pengetahuan dan ketarmpilan maka jumlah peserta dan sasaran kegiatan diperluas menjadi seluruh guru TK di wilayah PCA Umbulharjo. Keberhasilan pelatihan yang dicapai dilihat dari beberapa aspek baik secara pengetahuan maupun keterampilan.

Indikator keberhasilan dalam pelatihan ini dapat diukur melalui beberapa komponen yaitu jumlah peserta yang mengikuti pelatihan, perubahan pengetahuan dan keterampilan, implementasi hasil pelatihan, serta dampak yang diperolah. Manfaat lain yang diperoleh dari pelatihan ini adalah adanya implementasi kerjasama dengan beberapa sekolah yang telah bermitra dengan Prodi PG PAUD UAD sekaligus inisiasi terhadap kerjasama dengan sekolah lain.

Keberhasilan program pengabdian kepada masyarakat dalam pelatihan ini diukur dari jumlah partisipasi peserta melebihi rencana awal. Berdasarkan kehadiran peserta secara jumlah maupun sasaran mendapatkan antusiame yang tinggi. Rencana awal target peserta berjumlah 25 orang namun mengalami penambahan menjadi 50 orang dikarenakan keinginan dari guru TK A dan Kepala Sekolah mengikuti kegiatan ini. Selain jumlah antusiasme peserta juga diperlihatkan dalam proses pelatihan. Hasil pengamatan terlihat peserta menunjukkan kemauan untuk belajar, bertanya, dan menyelesaikan setiap tugas yang diberikan. Berikut gambar 1 foto kegiatan pelatihan yang dilaksanakan:
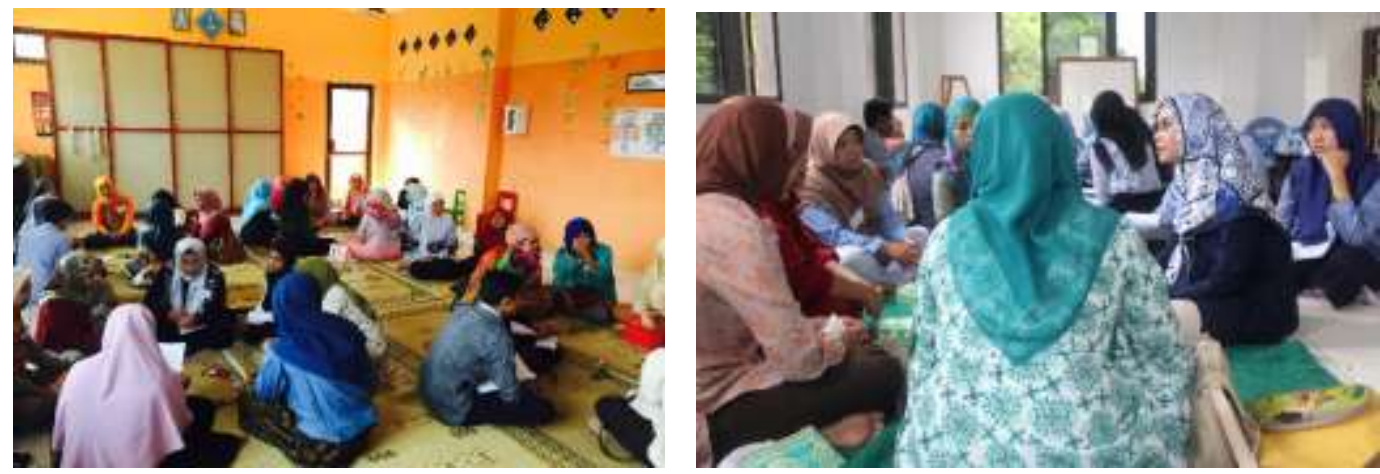

Gambar 1. Pelaksanaan Pelatihan NST.

Pelatihan Nst. (Nijmeegse Schoolbekwan Test) Untuk Deteksi Dini Kesiapan Anak (Avanti Vera Risti Pramudyani)| 228 
Program pelatihan ini juga memperlihatkan keberhasilan dengan adanya perubahan pengetahuan dan keterampilan bagi peserta. Pada awal pelatihan diperoleh data terkait pengetahuan dan keterampilan peserta mengenai konsep kesiapan sekolah dan intrumen deteksi dini kepada anak usia dini sebagai berikut:

1. Guru belum menjadikan deteksi dini sebagai salah satu aktivitas yang sama pentingnya dengan penyusunan kurikulum.

2. Pengetahuan guru terkait deteksi dini juga masih terbatas hanya psikolog dan tenaga medis atau kesehatan yang berhak melakukan deteksi dini.

3. Deteksi dini yang dilakukan guru masih sebatas pada aspek perkembangan fisik meliputi pengukuran Tinggi Badan (TB), Berat Badan (BB), dan Lingkar Kepala (LK).

4. Pengetahuan guru tentang NST sebagai alat deteksi kesiapan sekolah masih sangat terbatas pada informasi umum saja.

5. Guru juga masih menganggap bahwa kesiapan sekolah anak memasuki jenjang SD hanya ditandai dengan umur biologis.

6. Pemahaman guru terkait kesiapan sekolah masih disamakan dengan kesiapan belajar.

Berdasarkan kondisi awal tersebut proses pelatihan dilakukan dengan berbagai metode seperti ceramah, diksusi, praktek, serta Self and group Reflection. Materi diawali dengan mengenalkan konsep kesiapan sekolah dengan memberikan penjelasan indikator anak yang siap sekolah dilihat dari berbagai aspek perkembangan. Selanjutnya peserta diminta untuk berdiskusi mengidentifikasi anak dikelas masing-masing dan mengelompokkan sesuai dengan kesiapannya. Pada materi pengenalan konsep NST. Peserta diberikan pengetahuan tentang tujuan penggunaan alat NST serta Form A sebagai pengukur kematangan anak dan Form B sebagai evaluasi. Dalam materi ini peserta diberikan sub-test dalam alat ukur ini meliputi: (1) pengamatan dan kemampuan membedakan, (2) motorik halus, (3) pengertian tentang jumlah, ukuran dan perbandingan, (4) ketajaman pengamatan, (5) pengamatan kritis, (6) konsentrasi, (7) daya ingat, (8) pengertian tentang objek dan penilaian tentang situasi, (9) memahami cerita, (10) mengambar orang.

Proses pelatihan juga memberikan kesempatan kepada peserta untuk mempraktekkan pengetahuan yang diberikan. Setiap peserta mendapat form NST lengkap dan instruksi kerja untuk masing-masing sub-test. Pada saat simulasi, peserta dibagi ke 
dalam beberapa kelompok kecil agar bergantian berperan sebagai fasilitator tes. Desain simulasi ini memang menggunakan model klasikal meskipun NST sebenarnya bisa diadministrasikan secara individu. Setelah simulasi, peserta diberi tugas untuk mempraktekkan tes NST pada anak didik di sekolah masing-masing, minimal kepada 4 orang anak.

Hasil praktek tersebut dipresentasikan dalam pelatihan kembali untuk diberikan masukan dan saran terkait praktek yang dilakukan. Berdasarkan praktek di lapangan ini teridentifikasi beberapa kesulitan yang dialami peserta antara lain: mood anak cenderung naik turun sehingga sulit menyelesaikan tes hingga selesai, guru kesulitan menjaga ritme dalam kelompok agar bersama-sama menyelesaikan tiap sub-test, isian test tidak lengkap, dan kesalahan dalam pemberian instruksi. Namun dapat diketahui juga bahwa sebagian besar guru sudah mampu mengadministrasikan tes dengan baik.

Pada sesi terakhir dilakukan Self and group Reflection dengan tujuan untuk mengevaluasi proses pelatihan baik secara teknis maupun secara materi. Metode ini juga membantu peserta mengkomunikasikan kemampuan yang dimiliki untuk dibagikan dalam kelompoknya dan memahami antar anggota kelompok serta memberikan bantuan bagi anggota kelompok yang masih mengalami kesulitan dalam mempraktekkan ataupun memahami materi.

Kegiatan pengabdian kepada masyarakat yang diselenggarakan atas kerjasama LPPM UAD dengan PCA Umbulharjo dalam pelaksanaannya menemui kendala ialah peserta pengabdian (guru) kesulitan untuk mendapatkan data dari seluruh pertanyaan tes karena keterbatasan waktu dengan peserta didik dan kondisi peserta didik yang tergolong moody.

\section{B. PEMBAHASAN}

Pelatihan Penggunaan NST. (Nijmeegse Schoolbekwan Test) Untuk Deteksi Dini Kesiapan Anak Masuk Sekolah Dasar dilaksakan dengan tujuan memberikan perubahan pengetahuan kepada guru. Berdasarkan hasil pelatihan diawal pelatihan guru belum mengetahui tentang perbedaan kesiapan sekolah dan kesiapan belajar, namun setelah diberikan materi guru mampu mengidentifikasi kesiapan yang dimiliki oleh anak didik dikelasnya. Salah satu contoh hasil perubahan tersebut guru mampu melihat kesiapan sekolah yang telah dikuasai salah satu anak yaitu, mampu duduk dengan tenang ketika mendengarkan guru bercerita dalam jangka waktu lebih dari 5 menit, melakukan 2 - 3 instruksi guru dalam satu waktu, dapat belajar bersama dengan teman tanpa terganggu. Pelatihan Nst. (Nijmeegse Schoolbekwan Test) Untuk Deteksi Dini Kesiapan Anak (Avanti Vera Risti Pramudyani)| 230 
Hal tersebut sesuai dengan pendapat dari (Kagan M. , 1992), anak yang memiliki kesiapan sekolah akan menunjukkan perilaku seperti duduk dengan tenang dikelas dan merespon setiap instruksi guru. Ciri-ciri tersebut juga disampaikan oleh (Janus, et al., 2007), anak mampu memenuhi keinginan sekolah yaitu bekerja bersama, mendengarkan guru, dan manfaat lain yang akan diperoleh selama aktivitas pendidikan yang disediakan sekolah.

Form NST yang dikembangakan oleh Kemmler \& Hekhausen (dalam Monks, F. J., Rost, H., \& Coffie, N. H., 1978), berupa kuesioner kesiapan anak yang dapat digunakan oleh guru secara langsung berisi perilaku yang anak. Guru dalam praktek mampu melihat perilaku anak dalam sebuah kelompok, kesungguhan dan ketekunan anak dalam mengerjakan lembar kerja serta menyelesaikan dengan tepat waktu, dan keinginan untuk memperolah prestasi meskipun dalam lingkup sederhana seperti menjadi pemimpin kelompok saat berdoa.

Hasil dari pelatihan ini juga membekali guru untuk jeli dalam melihat perilaku yang ditunjukkan anak ketika masih dengan orangtua disekitar anak. Anak yang mudah untuk berpamitan dengan orangtua didepan gerbang sekolah dipahami guru sebagai salah satu bentuk kesiapan anak. Di dalam kelas anak yang telah siap dapat diperlihatkan dengan mampu menyelesaikan konflik sederhana yaitu rebutan mainan pada saat bermain dengan teman sekelas. Bahkan guru mulai mengurangi perannya dalam konflik sederhana yang anak hadapi di sekolah sebagai bagian dari proses anak sudah tidak perlu mencari dukungan dari guru. Peran guru lebih banyak menjadi pengamat atau observer bagi anakanak yang mulai menunjukkan kesiapan sekolah. Guru juga memperoleh pemahaman bahwa anak yang siap tidak lagi menunjukkan keluh kesah apabila diberikan kegiatan yang kompleks, anak menunjukkan sebaliknya mulai berlatih untuk beradaptasi apabila kegiatan belajar yang disediakan semakin banyak. Bahkan beberapa anak semakin cepat menyelesaikan suatu kegiatan dan guru semkain merasa bahwa hal tersebut adalah bagian dari perubahan pola belajar anak yang siap masuk SD.

Hal yang paling dirasakan oleh guru setelah memperoleh pelatihan ini adalah guru semakin peka bahwa semakin siap seorang anak memasuki jenjang SD maka anak akan memperlihatkan kemandirian dengan menemukan sendiri solusi atas permasalahan yang dihadapi dikelas baik dengan teman sekelas maupun dengan kondisi atau situasi pembelajaran. Kesemua perilaku tersebut sesuai dengan indikator kesiapan anak yang tercantum dalam NST sebagaimana yang dikembangkan Kemmler \& Hekhausen, (dalam Monks, F. J., Rost, H., \& Coffie, N. H., 1978). 


\section{DAMPAK}

1. Peserta yaitu guru TK memiliki kemauan untuk melakukan deteksi dini untuk kesiapan SD bagi anak TK B dengan NST. di tahun ajaran 2019/2020.

2. Peserta berkeinginan untuk mengikuti kegiatan yang serupa secara terus menerus agar meningkatkan kemampuan dalam melakukan deteksi dini.

\section{SIMPULAN}

Kegiatan pengabdian kepada masyarakat dengan Peningkatan Profesionalisme Guru Melalui Pelatihan Penggunaan NST. (Nijmeegse Schoolbekwan Test) Untuk Deteksi Dini Kesiapan Anak Masuk Sekolah Dasar yang dilaksanakan pada bulan November - Desember 2018 bertempat di TK ABA Nitikan, Umbulharjo, Yogyakarta dapat disimpulkan bahwa;

1. Pengetahuan peserta akan deteksi diri perkembangan anak usia dini masih sangat terbatas.

2. Animo peserta pelatihan diluar rencana pelatihan yaitu keikutsertaan seluruh guru baik dari layanan TK A sampai dengan TK B

3. Kerjasama yang solid antara sekolah, PCA Umbulharjo, dan LPPM UAD selama proses pelaksanaan program sehingga berjalan sesuai dengan rencana.

Berdasarkan pelaksanaan pelatihan yang telah terselenggara, sebaiknya untuk langkah selanjutnya perlu:

1. Adanya pelatihan lanjutan dan berkala agar program dapat dikembangkan dan menumbuhkan keinginan menerapkan deteksi dini di lembaga pendidikan masingmasing.

2. Program kegiatan pengabdian yang dilakukan sebaiknya dengan jangka waktu tertentu misal 2 tahun berturut-turut agar keberhasilan dan efektifitas program dapat diketahui.

\section{DAFTAR PUSTAKA}

Angelo, T., \& Cross, K. (1993). Classroom assessment techniques: A handbook for college teachers. San Francisco: Jossey-Bass Publishers.

Deliviana, E. (2017, Juli). Mempersiapkan Anak Masuk Sekolah Dasar. Jurnal Dinamika Pendidikan, 10(2), 119-133.

Janus, M., \& Gaskin, A. (2014). School Readiness. In: Michalos AC (Ed.). Encyclopedia of Quality of Life and Well-Being Research. Dordrecht, Netherlands: Springer. 
Janus, M., Brinkman, S., Duku, E., Herztman, C., Santos, R., Sayers, \& Schroeder, M. (2007). "The Early Development Instrument: A PopulationBased Measure for Communities". A handbook on development, properties, and use. Ontario: Offord Centre for Child Studies.

Kagan, M. (1992). Readiness Past, Present, and Future: Shaping the Agenda. Young Children, 48-53.

Kagan, S. (1990). Readiness 2000: Rethingking rhetoric and responsibility. Phi Delta Kappan, 72(4), 272 - 289.

Kebudayaan, P. D. (2017). Buku Saku Ikhtisar Data Pendidikan. Jakarta: Kementerian Pendidikan Dan Kebudayaan.

Kementerian Pendidikan dan Kebudayaan. (2014). Statistik Persekolahan PAUD 2013/2014. Kementerian Pendidikan dan Kebudayaan, Pusat Data dan Statistik Pendidikan. Jakarta Pusat: PDSP Kemdikbud.

Kusuma, A. D. (2016). Identifikasi Kesulitan Belajar Siswa Kelas V SD N Sosorowijayan Kota Yogyakarta. Jurnal Pendidikan Guru Sekolah Dasar, 3, 169.

Mariyati, L. I., \& Affandi, G. R. (2016, Agustus). Tepatkah NIJMEEGSE SCHOOLBEKWAAMHEIDS TEST (NST) Untuk Mengukur Kesiapan Siswa Sekolah Dasar Awal PAda Konteks Indonesia? (Analisis Emipirik Berdasarkan Teori Tes Klasik). Jurnal Ilmiah Psikologi Terapan, 04(02), 194 - 211.

Monks, F. J., Rost, H., \& Coffie, N. H. (1978). Nijmeegse Schoolbekwaamheids Test.

Natalia, M. D. (2013, Januari 14). www.solopos.com. (Rochimawati, Ed.) Retrieved Juni 09, 2017, from www.solopos.com/pendidikan: http://www.solopos.com/2013/01/14/pendidikan-usia-bukan-lagi-patokan-masuk-sd368364

Sanjaya, W. (2010). Strategi Pembelajaran Berorientasi Standar Proses Pendidikan. Jakarta: Kencana.

Sartika, D., Halimah, D., \& Annisa, N. (2011). Studi Eksplorasi Mengenai Kesiapan Anak Masuk SD Ditinjau Dari Hasil Tes NST di PAUD Cihanjuang dan PAUD Cikutra Indah Bandung. Prosiding Seminar Nasional Penelitian dan PKM: Sosial, Ekonomi, dan Humaniora. 2, pp. 9 - 18. Bandung: UNISBA.

Wiwik , S. (2005). Kesiapan Bersekolah Ditinjau Dari Jenis Pendidikan Pra Sekolah Anak dan Tingkat Pendidikan Orangtua. Psikologia, 1(1), 1. 


\section{UCAPAN TERIMA KASIH}

Terima kasih disampaikan kepada Lembaga Penelitian dan Pengabdian Kepada Masyarakat (LPPM) UAD yang telah membiayai kegiatan pelatihan ini. PCA Umbulharjo atas kerjasamanya serta Kepala Sekolah dan guru di TK ABA atas kesediaannya sebagai peserta pelatihan. Seluruh pihak yang memberikan bantuan sehingga artikel ini dapat dimuat dalam jurnal ini. 